\title{
Comparison of physiological and flowering parameters of main and off season by using different plant nutrients and growth hormone in mango (Mangifera indica L.) cv. Bangalora
}

\section{R Anusuya, RM Vijayakumar, S Srividhya \& R Sivakumar}

Journal of Agriculture and Ecology

Volume-5 (June, 2018)

ISSN: $2456-9410$

\section{Journal of Agriculture}

and Ecology

ISSN: 2456-9410

Volume: 5

Journal of Agriculture and Ecology (2018) 5: 76-82

http://doi.org/10.53911/JAE.2018.5109 


\title{
Comparison of physiological and flowering parameters of main and off season by using different plant nutrients and growth hormone in mango (Mangifera indica L.) cv. Bangalora
}

\author{
R Anusuya ${ }^{1} \not$, RM Vijayakumar ${ }^{1}$, S Srividhya $^{2} \&$ R Sivakumar ${ }^{2}$ \\ ${ }^{1}$ Department of Fruit Crops, HC \& RI, Tamil Nadu Agriculture University, Coimbatore - 03 \\ ${ }^{2}$ Regional Research Station, Paiyur - 635112 \\ Corresponding author: R Anusuya, E-mail anusuya7799@gamil.com
}

\section{Article Info}

Article history

Received: 02 August 2018

Accepted: 27 August 2018

Available online: 28

August 2018

Key Words: Mango, Bangalora, off season, main season, physiology, flowering.

\begin{abstract}
A field experiment was conducted at Regional Research Station, Paiyur during the year 2017-2018, to improve the physiological and flowering parameters using various plant growth regulators and nutrients. Observations were recorded on physiological and floral parameters. The chlorophyll 'a' $(2.21 \mathrm{mg} / \mathrm{g})$, 'b' $(1.80 \mathrm{mg} / \mathrm{g})$, total chlorophyll content $(2.68$ $\mathrm{mg} / \mathrm{g}$ ), chlorophyll index (57.98) and total soluble protein content (13.96 $\mathrm{mg} / \mathrm{g}$ ) were higher in the treatment PBZ (paclobutrazol) @ $0.75 \mathrm{~g}$ a.i. per $\mathrm{m}^{2}+\mathrm{KNO}_{3}(1 \%)+\mathrm{NAA}(20 \mathrm{ppm})$ during the main season. The least number of days were taken for initiation of first flowering (61.00 days) in the same treatment during the main season. Number of hermaphrodite flowers per panicle (458.29), length of panicle $(43.63 \mathrm{~cm})$ and number of panicles per $\mathrm{m}^{2}$ (36.33), were higher during the main season comparing the off season crop in the same treatment.
\end{abstract}

Copyright (C2018 Anusuya et al., This is an open access article published under the terms of the Creative Commons Attribution License, which permits unrestricted use, distribution, and reproduction in any medium, provided the original work is properly cited.

Preferred citation: Anusuya R, Vijayakumar RM, Srividhya S \& Sivakumar R. 2018. Comparison of physiological and flowering parameters of main and off season by using different plant nutrients and growth hormone in mango (Mangifera indica L.) cv. Bangalora. Journal of Agriculture and Ecology, 5: 76-82; http://doi.org/10.53911/JAE.2018.5109.

\section{Introduction}

Mango (Mangifera indica L.) is an important fruit crop of tropical and sub tropical regions belonging to the family Anacardiaceae with its origin in South East Asia. It exhibits wide variations in growth habit, flowering and fruiting. India is the largest producer of mango occupying about 2.26 lakh thousand hectares, with production of 20.7 million tonnes and productivity about 9.1MT/ha (India Stat 2017-2018). Off season fruiting in mango refers to bearing of fruits at a time different from the peak season of fruiting. The off season mango production is predominant in tropical countries viz., Thailand, Philippines, Indonesia and some parts of peninsular India especially, Kanyakumari and Courtallam of Tamil Nadu due to favourable temperature and relative humidity prevailing. Orchard efficiency and productivity of mango is affected by problems of biennial bearing, high fruit-drop during 
initial stages of fruit development and unfavourable environmental conditions resulting in low fruit set (Murti \& Upreti 2000; Kumar et al. 2016). The plant growth retardants especially paclobutrazol, has been found beneficial in combating some of the production related problems. The foliar application of plant growth regulators and nutrients have very important role in improving the flowering and productivity of fruits. Various studies have earlier reported that foliar spray of plant growth regulators and nutrients in different fruit crops cause significant response in improving flowering and yield parameters Hedge et al. (2018). As for physiological, flowering and fruit yield parameters, most of the earlier studies are restricted to the main season and information on off season is scanty. Hence, the present study was taken up to find out the comparison of physiological and flowering attributes of main and off season mango (Mangifera indica L.) cv. Bangalora.

\section{Material and Methods}

The present investigation was conducted at Regional Research Station, Paiyur during the year 2017-2018. The study was conducted in a farmer's field, which was located at Gurugapatti village, Pochampalli taluk, Krishnagiri district. The experimental site is geographically located at latitude $11^{\circ} 09^{\prime} \mathrm{N}$, longitude $76^{\circ} 57^{\prime} \mathrm{E}$ and altitude $426.76 \mathrm{~m}$ above MSL. The experiment was laid out in a Randomized Block Design (RBD), with eight treatments and replicated thrice in both off and main seasons. Twenty five years old uniform sized trees of mango cv. Bangalora spaced at $10 \times 10 \mathrm{~m}$ were selected for this study. Treatment details of the experiment are $\quad \mathrm{T}_{1}$ - Absolute control, $\mathrm{T}_{2^{-}}$PBZ @ $0.75 \mathrm{~g}$ a.i. per $\mathrm{m}^{2}$ (control), $\mathrm{T}_{3^{-}}$ PBZ @ 0.75 g a.i. per $\mathrm{m}^{2}+\mathrm{K}_{2} \mathrm{SO}_{4}(1 \%), \mathrm{T}_{4}-$ PBZ @ 0.75 g a.i. per $\mathrm{m}^{2}+\mathrm{MAP}(1 \%), \mathrm{T}_{5}$ PBZ @ 0.75g a.i. per $\mathrm{m}^{2}+\mathrm{KNO}_{3}(1 \%), \mathrm{T}_{6}-$ PBZ @ 0.75 g a.i. per $\mathrm{m}^{2}+\mathrm{K}_{2} \mathrm{SO}_{4}(1 \%)+$ NAA (20 ppm), T 7 - PBZ @ 0.75g a.i. per $\mathrm{m}^{2}$ $+\operatorname{MAP}(1 \%)+\mathrm{NAA}(20 \mathrm{ppm})$ and $\mathrm{T}_{8}-\mathrm{PBZ}$ @ $0.75 \mathrm{~g}$ a.i. per $\mathrm{m}^{2}+\mathrm{KNO}_{3}(1 \%)+\mathrm{NAA}(20$ ppm). The paclobutrazol concentration was calculated based on the diameter of the tree, and applied@0.75 g a.i per $\mathrm{m}^{2}$ which was done during the month of June 2017 for off season and September, 2017 for main season. Soil drenching of paclobutrazol was done as per the procedure reported by Burondkar \& Gunjate 1992. The foliar sprays of nutrients was imposed at different months viz., August $-15^{\text {th }}$, September $-15^{\text {th }}$ and October $-15^{\text {th }}$ for off season and November $30^{\text {th }}$, December $30^{\text {th }}$ and January $-30^{\text {th }}$ for main season.

Leaf chlorophyll content was determined by Arnon (1949) and expressed in $\mathrm{mg} / \mathrm{g}$. Soluble protein content was estimated by Lowery et al. (1951) and expressed in $\mathrm{mg} / \mathrm{g}$ Chlorophyll index was recorded using portable Chlorophyll Meter (Opti - science model, CCM-200 plus) and the average value was computed using method described by Monje \& Bugbee (1992). Randomly selected four shoots per tree were tagged over the tree for collecting the data on days taken for initiation of first flowering after spraying of chemicals. Number of panicles were counted per square meter area at four different locations on a tree with help of wooden frame $1 \mathrm{~m} \times 1 \mathrm{~m}$ dimension and the mean was expressed in numbers. At the time of full bloom, number of hermaphrodite flowers was 
counted from the randomly selected four panicles per tree and the mean value was expressed in numbers. Length of panicle was measured at full bloom stage. Four panicles were tagged per tree and the mean value was expressed in centimeter. Statistical analysis of data was done by adopting statistical procedures as per the methods of by Panse \& Sukhatme (1985).

\section{Results and Discussion}

Impact of plant growth regulators and nutrients on physiological parameters:

The chlorophyll content in plants plays a key role in maintaining the photosynthetic efficiency. The results of the present study revealed that among the two seasons studied, the 'leaf chlorophyll content' and 'chlorophyll index' were higher during the main season than the off season (Table 1). This might be due to the prevailing climatic conditions of the main season where the sunlight interception and temperature were favourable for the development of chlorophyll and photosynthesis. Among the different treatments tried, the highest chlorophyll ' $a$ ' content $(2.11 \mathrm{mg} / \mathrm{g})$, chlorophyll ' $\mathrm{b}$ ' content $(1.69 \mathrm{mg} / \mathrm{g})$, total chlorophyll content $(2.68$ $\mathrm{mg} / \mathrm{g}$ ) and chlorophyll index (45.60) was recorded in $\mathrm{T}_{8}$ - PBZ @ $0.75 \mathrm{~g}$ a.i. per $\mathrm{m}^{2}+$ $\mathrm{KNO}_{3}(1 \%)+$ NAA (20 ppm). Similar observations were reported by many workers earlier Subbaiah et al. (2018) in mango. The plants treated with paclobutrazol synthesized more cytokinin, which in turn enhanced chloroplast differentiation, chlorophyll biosynthesis and prevented chlorophyll degradation (Xia et al. 2018). Application of paclobutrazol blocks the terpenoid pathway which normally leads to GA (Gibberellic Acid) biosynthesis and an intermediate compound 'phytol' is produced which in turn leads to chlorophyll synthesis (Bai et al. 2004). In the light of above theories, the higher chlorophyll content recorded by application of paclobutrazol. Potassium is responsible for energy production in the form of ATP (Adenosine triphosphate) and NADPH (Nicotinamide Adenine Dinunucleotide Phosphate Hydrogen) in chloroplasts by maintaining balanced electric charges in plants (Kumar \& Kumar 2007; Yashwanti et al. 2016). Regarding soluble protein, in the present investigation, with regard to two seasons, the highest amount was observed during the main season (Table 1). Regarding the treatments, the maximum 'total soluble protein' was recorded in $(13.96 \mathrm{mg} / \mathrm{g})$ plants treated with $\mathrm{T}_{8}-\mathrm{PBZ} @ 0.75 \mathrm{~g}$ a.i. per $\mathrm{m}^{2}+$ $\mathrm{KNO}_{3}(1 \%)+$ NAA $(20 \mathrm{ppm})$. In contrast, the lowest soluble protein content was registered in the absolute control where no paclobutrazol was applied.

Table 1. Effect of different plant growth regulators and nutrients on physiological parameters in mango cv. Bangalora

\begin{tabular}{|c|c|c|c|c|c|c|c|c|c|c|}
\hline \multirow{2}{*}{$\begin{array}{c}\text { Treatments } \\
\text { Seasons }\end{array}$} & \multicolumn{2}{|c|}{$\begin{array}{l}\text { Chlorophyll a } \\
\qquad\left(\mathrm{mg} \mathrm{g}^{-1}\right)\end{array}$} & \multicolumn{2}{|c|}{$\begin{array}{l}\text { Chlorophyll b } \\
\quad\left(\mathrm{mg} \mathrm{g}^{-1}\right)\end{array}$} & \multicolumn{2}{|c|}{$\begin{array}{c}\text { Total } \\
\text { chlorophyll } \\
\text { content } \\
\left(\mathrm{mg} \mathrm{g}^{1}\right)\end{array}$} & \multicolumn{2}{|c|}{$\begin{array}{c}\text { Chlorophyll } \\
\text { index }\end{array}$} & \multicolumn{2}{|c|}{$\begin{array}{l}\text { Total soluble } \\
\text { protein } \\
\left(\mathrm{mg} \mathrm{g}^{-1}\right)\end{array}$} \\
\hline & $\begin{array}{c}\text { Off } \\
\text { season }\end{array}$ & $\begin{array}{l}\text { Main } \\
\text { season }\end{array}$ & $\begin{array}{c}\text { Off } \\
\text { season }\end{array}$ & $\begin{array}{l}\text { Main } \\
\text { season }\end{array}$ & $\begin{array}{c}\text { Off } \\
\text { season }\end{array}$ & $\begin{array}{l}\text { Main } \\
\text { season }\end{array}$ & $\begin{array}{c}\text { Off } \\
\text { season }\end{array}$ & $\begin{array}{l}\text { Main } \\
\text { season }\end{array}$ & $\begin{array}{c}\text { Off } \\
\text { season }\end{array}$ & $\begin{array}{l}\text { Main } \\
\text { season }\end{array}$ \\
\hline
\end{tabular}


Journal of Agriculture and Ecology, 2018, Vol.5, 76-82

http://saaer.org.in

\begin{tabular}{ccccccccccc}
\hline $\mathrm{T}_{1}$ & 1.18 & 1.24 & 0.71 & 1.33 & 1.04 & 1.39 & 25.60 & 38.00 & 8.81 & 9.00 \\
$\mathrm{~T}_{2}$ & 1.51 & 1.45 & 0.82 & 1.41 & 1.80 & 2.09 & 30.65 & 40.10 & 9.38 & 10.14 \\
$\mathrm{~T}_{3}$ & 1.52 & 1.54 & 0.92 & 1.48 & 2.01 & 2.11 & 34.08 & 42.99 & 9.43 & 9.75 \\
$\mathrm{~T}_{4}$ & 1.61 & 1.37 & 1.01 & 1.55 & 1.61 & 1.67 & 33.95 & 42.69 & 9.69 & 11.30 \\
$\mathrm{~T}_{5}$ & 1.65 & 1.31 & 1.09 & 1.42 & 2.35 & 2.37 & 37.05 & 43.66 & 10.02 & 12.22 \\
$\mathrm{~T}_{6}$ & 1.86 & 1.57 & 1.24 & 1.36 & 2.21 & 2.21 & 39.24 & 48.00 & 12.13 & 12.41 \\
$\mathrm{~T}_{7}$ & 1.72 & 1.58 & 1.15 & 1.59 & 1.69 & 1.82 & 38.60 & 44.89 & 11.12 & 11.42 \\
$\mathrm{~T}_{8}$ & 2.11 & 2.21 & 1.69 & 1.80 & 2.54 & 2.68 & 45.60 & 57.98 & 13.12 & 13.96 \\
\hline $\mathrm{SEd}$ & 0.04 & 0.02 & 0.03 & 0.04 & 0.25 & 0.04 & 0.54 & 2.31 & 0.24 & 0.23 \\
$\mathrm{CD}$ & & & & & & & & & & \\
$(\mathrm{p}=0.05)$ & 0.08 & 0.04 & 0.06 & 0.09 & 0.54 & 0.08 & 1.15 & 4.96 & 0.52 & 0.49 \\
\hline
\end{tabular}

Impact of plant growth regulators and nutrients on floral parameters:

The timing and intensity of flowering directly determine the yield. Among the two types of flowers noticed, the number of hermaphrodite flowers directly influences the yield. Concerning seasons, the flowering parameters were found be at a higher level during main season due to the increasing soluble protein enzyme, RuBP carboxylase. This is the most abundant protein present in leaves and involved in $\mathrm{CO}_{2}$ fixation which directly influences photosynthetic efficiency. Among the different treatments, lesser number of days (61.00 days) were taken for initiation of first flowering in the treatment PBZ @ $0.75 \mathrm{~g}$ a.i. $\mathrm{m}^{-2}+\mathrm{KNO}_{3}(1 \%)+\mathrm{NAA}(20 \mathrm{ppm})$ (Table 2). It may be due to suppressing activity of paclobutrazol on gibberellins, causing an early reduction of endogenous gibberllic acid levels in shoots by blocking the conversion of ent kaurene to ent kaurenol (Srilatha et al. 2014). Regarding the other chemical $\mathrm{KNO}_{3}$ that was applied along with PBZ, it was already reported that $\mathrm{KNO}_{3}$ induces nitrate reductase activity, a key enzyme in nitrate assimilatory pathway for amino acid synthesis particularly methionine. Methioine has been reported to promote mango flowering and is a precursor of ethylene (Sudha et al. 2012). The results obtained are in agreement with Subbaiah et al. (2018) and Burondkar et al. (2013) who reported that PBZ application led to 30 days earlier panicle emergence in mango. With respect to the number of hermaphrodite flowers per panicle, compared both the seasons, the highest number of hermaphrodite flowers was recorded in the main season than off season. Regarding the growth regulator and nutrient applications, PBZ @ $0.75 \mathrm{~g}$ a.i. per $\mathrm{m}^{2}+\mathrm{KNO}_{3}(1 \%)+$ NAA $(20 \mathrm{ppm})$ led to the production of highest (458.29) number of hermaphrodite flowers. Paclobutrazol might have resulted in higher reserves of carbohydrates in shoots by its anti - gibberellin nature (Agnihotri et al. 2016; Subbaiah \& Reddy 2018). 
Table 2. Effect of different plant growth regulators and nutrients on flowering parameters in mango cv. Bangalora

\begin{tabular}{|c|c|c|c|c|c|c|c|c|}
\hline \multirow{2}{*}{$\begin{array}{c}\text { Treatments } \\
\text { Seasons }\end{array}$} & \multicolumn{2}{|c|}{$\begin{array}{l}\text { Days taken for } \\
\text { initiation of first } \\
\text { flowering }\end{array}$} & \multicolumn{2}{|c|}{$\begin{array}{c}\text { Number of } \\
\text { hermaphrodite } \\
\text { flowers per panicle }\end{array}$} & \multicolumn{2}{|c|}{$\begin{array}{l}\text { Length of the } \\
\text { panicle }(\mathrm{cm})\end{array}$} & \multicolumn{2}{|c|}{$\begin{array}{c}\text { Number of } \\
\text { panicles per } \mathrm{m}^{2}\end{array}$} \\
\hline & $\begin{array}{r}\text { Off } \\
\text { season }\end{array}$ & $\begin{array}{l}\text { Main } \\
\text { season }\end{array}$ & $\begin{array}{c}\text { Off } \\
\text { season }\end{array}$ & $\begin{array}{l}\text { Main } \\
\text { season }\end{array}$ & $\begin{array}{c}\text { Off } \\
\text { season }\end{array}$ & $\begin{array}{c}\text { Main } \\
\text { season }\end{array}$ & $\begin{array}{r}\text { Off } \\
\text { season }\end{array}$ & $\begin{array}{l}\text { Main } \\
\text { season }\end{array}$ \\
\hline $\mathrm{T}_{1}$ & 0.00 & 89.22 & 0.00 & 287.75 & 0.00 & 26.99 & 0.00 & 27.83 \\
\hline $\mathrm{T}_{2}$ & 109.27 & 70.56 & 356.04 & 362.25 & 28.21 & 33.37 & 18.80 & 32.00 \\
\hline $\mathrm{T}_{3}$ & 105.87 & 73.00 & 375.45 & 387.04 & 30.65 & 33.54 & 21.34 & 31.13 \\
\hline $\mathrm{T}_{4}$ & 93.13 & 70.78 & 399.04 & 391.83 & 29.71 & 35.84 & 21.17 & 33.50 \\
\hline $\mathrm{T}_{5}$ & 108.33 & 67.22 & 402.53 & 362.25 & 31.41 & 36.40 & 26.44 & 33.83 \\
\hline $\mathrm{T}_{6}$ & 101.73 & 71.89 & 407.96 & 419.00 & 30.54 & 37.70 & 25.97 & 34.17 \\
\hline $\mathrm{T}_{7}$ & 99.60 & 72.11 & 390.46 & 384.67 & 30.12 & 36.93 & 22.15 & 32.17 \\
\hline $\mathrm{T}_{8}$ & 89.60 & 61.00 & 447.99 & 458.29 & 36.24 & 43.63 & 31.45 & 36.33 \\
\hline $\mathrm{SE} \mathrm{d}$ & 3.24 & 4.25 & 16.24 & 23.24 & 0.61 & 0.83 & 2.83 & 0.72 \\
\hline $\begin{array}{c}C D \\
(p=0.05)\end{array}$ & 6.97 & 9.01 & 34.84 & 49.86 & 1.31 & 1.79 & 6.07 & 1.55 \\
\hline
\end{tabular}

The length of panicle was also found to be greater in the main season than the off season. The favourable environmental factors that prevailed during the main season might have caused this effect. Among these treatments, PBZ @ $0.75 \mathrm{~g}$ a.i. per $\mathrm{m}^{2}+$ $\mathrm{KNO}_{3}(1 \%)+\mathrm{NAA}(20 \mathrm{ppm})$ led to the production of highest $(43.63 \mathrm{~cm})$ length of panicle. NAA is a known auxin compound which has a profound role on cell division and elongation (Vijayalakshmi \& Srinivasan 1998). The 'number of panicles per $\mathrm{m}^{2}$ canopy area' is one of the major determinants of yield in mango. Among the seasons, the highest number of panicles per $\mathrm{m}^{2}$ canopy area was recorded (36.33) in the main season than in the off season. During the main season, the total chlorophyll was greater which caused higher photosynthetic efficiency thereby the number of panicles could have been increased. Among the different treatments, PBZ @ 0.75 g a.i. per $\mathrm{m}^{2}+\mathrm{KNO}_{3}(1 \%)+\mathrm{NAA}(20 \mathrm{ppm})$ led to the production of higher number of panicles per $\mathrm{m}^{2}$ canopy area.

\section{Conclusion}

In a nut shell, all the physiological and flowering parameters were found to be at their best level during the main season compared to the off season by application of PBZ @ 0.75 g a.i. per $\mathrm{m}^{2}+\mathrm{KNO}_{3}(1 \%)+$ NAA (20 ppm). This might be due to the prevailing climatic conditions of the main season.

\section{Acknowledgement}

I sincerely thank Professor and Head, Regional research station, Paiyur for providing laboratory facilities and farmers 
for providing field for carrying out this

\section{References}

Agnihotri MK, Sarolia DK, Singh V \& Shukla AK. 2016. Crop regulation in guava cv. Sardar as influenced by chemicals and cultural practices under semi arid conditions of Rajasthan. Journal of Agriculture and Ecology, 1: 85-90.

Arnon DI. 1949. Copper enzymes in isolated chloroplasts. Polyphenoloxidase in Beta vulgaris. Plant physiology, 24 (1), 1-15.

Bai S, Chaney W \& Qi Y. 2004. Response of cambial and shoot growth in trees treated with paclobutrazol. Journal of Arboriculture, 30 (3), 137-145.

Burondkar M \& Gunjate R. 1992. Control of vegetative growth and inductive of regular and early cropping in 'Alphonso' mango with paclobutrazol. Paper presented at the IV International Mango Symposium 341. doi:10.17660/ActaHortic. 1993.341.21

Hegde S, Adiga JD, Honnabyraiah M, Guruprasad T, Shivanna M \& Halesh G. 2018. Influence of Paclobutrazol on Growth and Yield of Jamun cv. Chintamani. Int. J. Curr. Microbiol. App. Sci, 7 (1), 1590-1599. doi: https://doi.org/10.20546/ijcmas.201 $\underline{8.701 .193}$

Kumar AR \& Kumar N. 2007. Sulfate of potash foliar spray effects on yield, quality, and post-harvest life of banana. Better crops, 91, 22. Retrieved from http://citeseerx.ist.psu.edu/viewdoc/dow nload?doi=10.1.1.521.9592\&rep=rep1\&t ype $=$ pdf

Kumar K, Srivastav M, Singh SK \& Vinod 2016. Ascertaining hybridity of study.

progenies in mango (Mangifera indica L.) using microsatellite (SSR) markers. Journal of Agriculture and Ecology, 2: $1-10$.

Lowry OH, Rosebrough NJ, Farr AL \& Randall RJ. 1951. Protein measurement with the Folin phenol reagent. Journal of biological chemistry, 193 (1): 265-275.

Monje OA \& Bugbee B. 1992. Inherent limitations of nondestructive chlorophyll meters: a comparison of two types of meters. Hort Science, 27 (1): 69-71.

Murti G \& Upreti K. 2000. Plant hormones. Advances in plant physiology. 3: 109148. Retrieved from https://www.cabdirect.org/cabdirect/abst $\mathrm{ract} / 20013091775$

Panse V \& Sukhatme P. 1985. Statical methods for Agricultural workers. ICAR. New Delhi.

Srilatha V, Reddy Y \& Prasad SS. 2014. Mango flowering physiology in response to paclobutrazol application. Souvenir, National Seminar-cum-Workshop on Physiology of Flowering in Perennial Fruit Crops. P-241-249.

Subbaiah KV, Reddy N, Padmavathamma A, Reddy M, Rao AD, Manjula R \& Reddy A. 2018. Effect of paclobutrazol on hermaphrodite flowers, leaf chlorophyll. International Journel of Current Microbiology and Applied Sciences, 7(4):1-7.

Subbaiah KV, Reddy NN \& Reddy MLN. 2018. Effect of paclobutrazol and other chemicals on yield and quality of mango cv. Banganpalli. International Journal of 
Science, Environment and Technology, 3 (6): 1809-1819.

Sudha R, Balamohan $\mathrm{T} \quad$ \& Soorianathasundaram K. 2012. Effect of foliar spray of nitrogenous chemicals on flowering, fruit set and yield in mango (Mangifera indica L.) cv. Alphonso. Journal of Horticultural Science, 7(2): 190-193.

Vijayalakshmi D \& Srinivasan PS. 1998. Induction of flowering in 'OFF' year mango cv. Alphonso as influenced by chemical and growth regulators. Annals of plant physiology, 12: 93-97. www.indiastat.com/agriculturedata/2/horticulture/118/stats.aspx

Xia X, Tang Y, Wei M \& Zhao D. 2018. Effect of Paclobutrazol Application on Plant Photosynthetic Performance and Leaf Greenness of Herbaceous Peony. Horticulturae, 4 (1): 5.

Yashwanti, Sharma MK, Singh D, Kamlesh Kumar K \& Sarolia DK. 2016. Microbudding in bael as influenced by foliar spray of NAA and BA on rootstock and scion. Journal of Agriculture and Ecology, 2: 32-36. 